\section{Response to: 'Phsician's global assessment is often useful in SLE, but not always: the case of clinical remission' by Zen et al}

We thank Dr Zen and colleagues for their interest in our article on the Physician's Global Assessment (PGA) ${ }^{1}$ in lupus, and for sharing their experience. ${ }^{2}$ Their comment focusses on the impact of a PGA (scored prior to reviewing complement and anti-DNA antibody tests) in association with the clinical Systemic Lupus Erythematosus Disease Activity Index (SLEDAI) (cSLEDAI) on the definition of clinical remission. Of note, the cSLEDAI captures haematology and renal activity measured in the laboratory, and differs from the SLEDAI only in the omission of serology. The objective of our study was not to evaluate serology per se, but to determine the impact of knowledge of all pertinent laboratory values on physician scoring of the PGA. We found that PGA scores determined with knowledge not only of serology, but also of haematology, urinalysis, proteinuria and acute phase reactants (C-reactive protein and erythrocyte sedimentation rate), correlated significantly better with an objective measure of disease activity, the SLEDAI-2K. Our data are therefore not correctly interpreted by Zen et al who state that "abnormal serology alone determined a median PGA increase of $0.54 \ldots$... Of interest, Zen and colleagues report that a PGA $\geq 0.5$ despite cSLEDAI-2K=0 associated with 'non-specific' patient-reported symptoms validating the premise that physicians do indeed consider a patient's experience when assessing disease activity.

Our data support the inclusion of laboratory evaluations, which include but are not limited to serological data, when scoring the PGA. The role of serology in a definition of remission in systemic lupus erythematosus is a separate issue, best resolved by assessing long-term patient outcomes in large cohorts. Our findings indicate that the PGA in such studies should be scored with knowledge of relevant laboratory data.

Anca Askanase, ${ }^{1}$ Shereen Oon $\odot{ }^{2}{ }^{2}$ Molla Huq, ${ }^{3}$ Alicia Calderone, ${ }^{2}$ Eric F Morand $\odot,{ }^{4}$ Mandana Nikpour, ${ }^{2}$ Cynthia Aranow $\odot^{5}$

${ }^{1}$ Department of Rheumatology, Columbia University College of Physicians and Surgeons, New York, New York, USA
${ }^{2}$ Rheumatology, St Vincent's Hospital, Fitzroy, Victoria, Australia

${ }^{3}$ Department of Medicine, University of Melbourne, Melbourne, Victoria, Australia

${ }^{4}$ School of Clinical Sciences, Monash University, Clayton, Victoria, Australia

${ }^{5}$ The Feinstein Institute for Medical Research, Manhasset, New York, USA

Correspondence to Dr Cynthia Aranow, The Feinstein Institute for Medical Research, Manhasset, NY 11030, USA; caranow@northwell.edu

Handling editor Josef S Smolen

Contributors All authors contributed to this reply.

Funding The authors have not declared a specific grant for this research from any funding agency in the public, commercial or not-for-profit sectors.

Competing interests None declared.

Patient and public involvement Patients and/or the public were not involved in the design, or conduct, or reporting or dissemination plans of this research.

Patient consent for publication Not required.

Provenance and peer review Commissioned; internally peer reviewed.

(c) Author(s) (or their employer(s)) 2020. No commercial re-use. See rights and permissions. Published by BMJ.

\section{Check for updates}

To cite Askanase A, Oon S, Huq M, et al. Ann Rheum Dis Epub ahead of print: [please include Day Month Year]. doi:10.1136/annrheumdis-2020-217687

Received 5 May 2020

Accepted 5 May 2020

\section{SLinked}

- http://dx.doi.org/10.1136/annrheumdis-2020-217611

Ann Rheum Dis 2020;0:1. doi:10.1136/annrheumdis-2020-217687

\section{ORCID iDs}

Shereen Oon http://orcid.org/0000-0002-6822-5711

Eric F Morand http://orcid.org/0000-0002-9507-3338

Cynthia Aranow http://orcid.org/0000-0001-9299-0053

\section{REFERENCES}

1 Aranow C, Askanase A, Oon S, et al. Laboratory investigation results influence physician's global assessment (PGA) of disease activity in SLE. Ann Rheum Dis 2020:pii: annrheumdis-2019-216753

2 Zen M, Saccon F, Gatto M, et al. Physicians'Global assessment is often useful in SLE, but not always: the case of clinical remission. Ann Rheum Dis 2020. 